\title{
Nutritional Quality of Tomato (Lycopersicon lycopersicum L.) Varieties as Influenced by Combined Application of Human Urine and Rock Phosphate
}

\author{
Adebiyi Samuel Egbebi*, Ezekiel Akinkunmi Akinrinde \\ Department of Agronomy, Faculty of Agriculture, University of Ibadan, Ibadan, Nigeria \\ Email: ^adebiyiegbebi@gmail.com, akinakinrinde@gmail.com
}

How to cite this paper: Egbebi, A.S. and Akinrinde, E.A. (2019) Nutritional Quality of Tomato (Lycopersicon lycopersicum L.) Varieties as Influenced by Combined Application of Human Urine and Rock Phosphate. Agricultural Sciences, 10, 622-637. https://doi.org/10.4236/as.2019.105048

Received: March 26, 2019

Accepted: May 10, 2019

Published: May 13, 2019

Copyright () 2019 by author(s) and Scientific Research Publishing Inc. This work is licensed under the Creative Commons Attribution International License (CC BY 4.0).

http://creativecommons.org/licenses/by/4.0/

\begin{abstract}
There has been increasing interest in the quality of food produced in the sub-Saharan Africa and organic fertilizers can be used as palliative for eradicating malnutrition and improving the livelihood of the populace. A study was conducted in two phases, $4 \times 5 \times 2$ and $2 \times 4$ factorial experiments in a completely randomized design with three replicates at the Department of Agronomy screenhouse, University of Ibadan, Nigeria. In the first experiment, five $\mathrm{N}$ levels $(0,20,40,60$ and $80 \mathrm{kgN} / \mathrm{ha})$ were combined with two P levels $(0$ and $20 \mathrm{kgP} / \mathrm{ha}$ ) using urea and single superphosphate, respectively and four varieties (Roma VF, UC82B, Rio grande and Roma savana) of tomatoes were used. In the second experiment, optimum rates (60 kgN and $20 \mathrm{kgP} / \mathrm{ha})$ from the first experiment formed the basis for the application of urea + SSP, urine + ORP, urea + SSP + urine + ORP and control. The best-performing varieties (Rio grande and Roma savana) in the first experiment were used. Data were subjected to analysis of variance. Combined application of $\mathrm{N}$ and $\mathrm{P}$ had higher $\mathrm{N}$ use efficiency and nutrient uptake than sole application of $\mathrm{N}$ or P. Urine + ORP based fertilizer mixtures were best for nutrient uptake and crop utilization of $\mathrm{N}$ and $\mathrm{P}$. Increasing $\mathrm{N}$ levels led to decrease in nutrient use efficiency. Application of urine + ORP and urea + SSP gave better fruit qualities. The descending order of varietal superiority with respect to nutrient uptake, utilization and quality was: Rio grande $>$ Roma savana $>$ Roma VF $>$ UC82B. Thus, urine + ORP based fertilizer mixtures have great potentials as substitutes for urea + SSP in the production of tomatoes.
\end{abstract}

\section{Keywords}

Tomato, Human Urine, Phytonutrient, Nutrient Uptake, Utilization Efficiency, 
Rock Phosphate

\section{Introduction}

Tomato products, the humble staple cuisines across the globe, are emerging as foods that hold particular promise in promoting health among the populace. Tomatoes are among the most popular vegetables in Nigeria, second only to potatoes [1]. Nigeria accounts for 2.2 million MT produced on an area of 574,441 ha, with average yield of $4 \mathrm{t} / \mathrm{ha}$ [2]. Tomato fruit is considered as one of the important sources of vitamin C, carotenoids and other minerals such as iron and phosphorous that are necessary for healthy growth. It was also affirmed that tomato fruits do not only constitute a great source of lycopene but also contain carotenoids with a high oxygen-radical scavenging and quenching capacity [3] [4]. Soils in sub-Saharan Africa have been found to be infertile and characteristically low in soil organic matter content and cannot support intensive cultivation due to the rapid rate of fertility decline when intensively cropped [5]. One of the ways to solve this problem is through the use of inorganic fertilizers such as urea and single superphosphate but the hazardous environmental consequences and their high cost make them not only undesirable but also uneconomical and out of reach of the poor farmers who dominate the Nigerian agricultural sector [6].

Human urine as an alternative contains plant nutrients (especially nitrogen) which are cheap, readily available and useful for increase in food production and improving soil fertility [7]. According to [8], the annual amount of human urine of one person corresponds to the amount of fertilizer needed to produce $250 \mathrm{~kg}$ of cereal that one person needs to consume per year; thus it is possible to have good quantity of human urine as fertilizer [9] for crop production. Human urine has been compared successfully with commercial chemical fertilizer using many types of vegetables and crops [10] [11].

The direct application of ground, natural rock phosphate as a source of phosphorus for crops is a practice that has been utilized with varying degrees of success over years. Phosphorus application on the other hand is known to initiate root growth in tomato, enhancing early establishment after transplanting from the nursery or after direct field seeding. Furthermore, in commercial screenhouses, the use of N-based fertilizer for tomato production often exceeds crop requirement [12]. Likewise, investigations have shown that increasing $\mathrm{N}$ application increases the concentration of vital chemical components e.g. phytonutrients [13]. It has also been observed that excess $\mathrm{N}$ can adversely affect fruit quality [14]. However, there is meagre information on the effects of combined application of human urine and Ogun rock phosphate (ORP) on nutrient uptake, use efficiency and nutritional quality of tomato. Thus, the main objective of this study was to evaluate the effects of these fertilizer treatments on nutrient 
uptake, use efficiency as well as nutritional quality of different tomato varieties.

\section{Materials and Methods}

\subsection{Soil Collection}

The soil collected was a loamy sand from Parry road with coordinates: latitude $7^{\circ} 27^{\prime} \mathrm{N}$ and longitude $3^{\circ} 53^{\prime} \mathrm{E}$ on an altitude of $321.5 \mathrm{~m}$ at the University of Ibadan, Ibadan, Nigeria in June 2016. Soils were sampled at $0-15 \mathrm{~cm}$ depth and were air dried, mixed properly and passed through $2 \mathrm{~mm}$ sieve, and then stored for physical and chemical analysis.

\subsection{Physical and Chemical Analysis}

Routine physical and chemical analysis of the soil samples were carried out as described in the laboratory manual of the department of Agronomy, University of Ibadan, for analysis of soil, plant and water by [15]. Otherwise, the method is stated. Particle size analysis was determined by the hydrometer method [16]. Soil $\mathrm{pH}$ was determined on a 1:2 (soil:water) ratio after 15 minutes equilibration period using a glass electrode calibrated to buffers $\mathrm{pH} 4,7$ and 9. Organic carbon was determined by the dichromate wet oxidation method [17]. Exchangeable acidity was extracted with $1 \mathrm{~N} \mathrm{KCl}$ and titrated against $0.01 \mathrm{~N} \mathrm{NaOH}$ as described by [18]. Total Nitrogen was determined by the Kjeldahl method as described by [19]. Exchangeable cations ( $\mathrm{Ca}, \mathrm{Mg}, \mathrm{K}$ and $\mathrm{Na}$ ) were extracted with 1 $\mathrm{N} \mathrm{NH4OAc} \mathrm{(pH} \mathrm{7)} \mathrm{at} \mathrm{a} \mathrm{soil:} \mathrm{extraction} \mathrm{solution} \mathrm{ratio} \mathrm{of} \mathrm{1:10} \mathrm{for} 15$ minutes at $105^{\circ} \mathrm{C}$. Micro nutrients such as $\mathrm{Fe}, \mathrm{Mn}, \mathrm{Cu}$ and $\mathrm{Zn}$ were extracted with $0.1 \mathrm{~N}$ $\mathrm{HCl}$ and their amounts were determined by Atomic Absorption Spectrophotometer. Phosphorus was extracted by Bray P-1 solution and the $\mathrm{P}$ in the extract determined by the Molybdenum blue colour method of [20].

\subsection{Screenhouse Experiments}

The investigation was carried out at the department of Agronomy screenhouse, University of Ibadan, Ibadan, Nigeria with the coordinates: latitude $7^{\circ} 34^{\prime} \mathrm{N}$ and longitude $3^{\circ} 54^{\prime} \mathrm{E}$ on an altitude of $234 \mathrm{~m}$. The screenhouse has relative humidity of $26 \%-84 \%$, temperature of $34^{\circ} \mathrm{C}-24^{\circ} \mathrm{C}$, and solar radiation is between 19.4 $\mathrm{MJ} / \mathrm{m}^{2} /$ day $-15.3 \mathrm{MJ} / \mathrm{m}^{2} /$ day. The phase 1 and 2 of the investigation were $4 \times 5 \times$ 2 and $2 \times 4$ factorial experiments, respectively in Completely Randomized Design with treatments replicated three times. The first phase involved five $\mathrm{N}$ levels $(0,20,40,60$ and $80 \mathrm{kgN} / \mathrm{ha})$ and two P levels ( 0 and $20 \mathrm{kgP} / \mathrm{ha})$ as urea and single superphosphate (SSP) respectively, were combined to give 10 fertilizer treatment combinations. These were tested on four varieties of tomatoes (Roma VF, UC82B, Rio grande and Roma savana) which are short, bushy and determinate types. The second phase involved application of optimum rates $(60 \mathrm{kgN}$ and 20 $\mathrm{kgP} / \mathrm{ha}$ ) determined from phase one equally supplied by the fertilizer sources. Apart from control, inorganic fertilizers (urea + SSP) at ratio 1:1, organic ferti- 
lizers (urine + ORP) at ratio 1:1 and organo-mineral fertilizer (OMF) mixtures (urea + SSP + urine + ORP) were applied at ratio 0.5:0.5:0.5:0.5. The two tomato varieties (Rio grande and Roma savana) certified as best in phase 1 were used. The four varieties of tomato were procured from Agrotropics (Technisem), Ibadan, Oyo State, Nigeria.

The first and second experiments were carried out on the same soil type with polythene bags of $5 \mathrm{~kg}$ capacity filled with $4.5 \mathrm{~kg}$ soil. Urea and superphosphate were applied a day prior to transplanting in the first experiment while in the second experiment, Ogun rock phosphate and human urine were applied two (2) weeks and three (3) days before transplanting respectively. Twenty eight days after sowing, healthy seedlings of uniform height (growth) were selected. At six weeks after transplanting (prior to first fruit production) in the first and second experiments, destructive samplings were carried out to determine the nutrient contents (nitrogen and phosphorus) and uptake. The above ground portions were weighed to determine the fresh weight, enveloped and oven dried to a constant weight at $80^{\circ} \mathrm{C}$ for $48 \mathrm{hrs}$ after which they were re-weighed. Proximate analysis was later carried out to determine the $\mathrm{pH}$, lycopene, $\beta$-carotene (vitamin A), ascorbic acid (vitamin C) and titratable acidity contents of ripened tomato fruits.

The nutrient uptake is calculated using the formula below:

Nutrient uptake $(\mathrm{g} / \mathrm{kg})=\%$ Nutrient content in plant tissue $\times$ DMY $(\mathrm{g} / \mathrm{plant})$; where DMY is the dry matter yield.

In the first and second experiment, the nitrogen and phosphorus use efficiencies were calculated based on fresh fruit weight and dry shoot biomass using the formula;

$$
\frac{Y_{f}-Y_{0}}{N_{a p p}} \quad(\text { Moll et al., 1982) }
$$

$Y_{\dot{F}}$ Yield produced with fertilizer; $Y_{0}$ : Yield of the control; $N_{a p p}$ : Unit of fertilizer applied.

\subsection{Nutrient Content, Human Urine and Ogun Rock Phosphate Analysis}

The properties were determined by the method outlined by [21]. Total Nitrogen was determined by the Kjeldahl method as described by [22], while total P was determined by the vanadomolybdate (yellow) method of [23].

\subsection{Proximate Analysis}

The $\mathrm{pH}$ was determined by washing the $\mathrm{pH}$ electrode with distilled water and placed in each sample. Readings were taken after few moments of stability. Titratable acidity was determined by transferring the sample into a $250 \mathrm{ml}$ conical flask. 4 - 5 drops of phenolphthalein indicator was added. $25 \mathrm{ml}$ burette was filled with $0.1 \mathrm{M}$ sodium hydroxide and titrated until the indicator turned 
pink/red and the titre volume of Sodium Hydroxide added was recorded. Calculation of percentage total titratable acidity (\% TTA) as lactic acid was obtained by multiplying the titre volume by 0.09 . The lycopene content was determined by grinding $20 \mathrm{ml}$ of the homogenized pulp in $25 \mathrm{ml}$ acetone and $20 \mathrm{ml}$ hexane and then absorbance was read at $501 \mathrm{~nm}$ using a colorimeter. Ascorbic acid was determined by weighing one red tomato and grinded up with a little glacial acetic acid in a mortar. The extracts was transferred quantitatively with distilled water into a $50 \mathrm{ml}$. volumetric flask and made up to the mark with more water, and filtered rapidly. $10 \mathrm{ml}$ of the filtrate was added into a conical flask with one drop of dilute acetic acid and titrated against the redox dye, 2:6 dichlorophenol indophenol solution in the burette. Calculated per $100 \mathrm{~g}$. of tomato. $B$-Carotene was determined by adding $1 \mathrm{ml}$. of tomato fruit to $25 \mathrm{ml}$. of normal alcoholic $\mathrm{KOH}$ and were heated under reflux until saponification is complete. After cooling, the mixture is titrated against $\mathrm{N} / 2 \mathrm{HC}$, using phenolphthalein as indicator. After titration with $\mathrm{HCl}$, the fatty acids was present as the potassium salts. The unsaponifiable matter in the mixture, after titration, is distill off the ether on an electric sand bath removing the last traces of solvent by applying gentle suction from the water pump. The unknown extracts and suitable standards are therefore compared at 440 millimicrons (blue filter) wavelength. All these methods followed the Association of Official Agricultural Chemist (AOAC) methods (1980).

\subsection{Data Analysis}

The collected data were subjected to analysis of variance using GENSTAT $4^{\text {th }}$ Edition, 2016. Means were separated using Duncan's Multiple Range Test (DMRT) at $5 \%$ level of significance.

\section{Results}

\subsection{Soil and Fertilizer Nutrient Sources Analysis}

The pre-cropping chemical properties and particle size distribution of the soil used in the study is shown in (Table 1). The pre-cropping soil analysis showed that the soil is loamy sand with good moisture retention properties. Most of its chemical properties are below the critical values, especially for nitrogen and phosphorus with values of $0.1 \mathrm{~g} / \mathrm{kg}$ and $3 \mathrm{mg} / \mathrm{kg}$ respectively. The organic carbon and potassium were $13.8 \mathrm{~g} / \mathrm{kg}$ and $0.5 \mathrm{cmol} / \mathrm{kg}$, respectively. The $\mathrm{pH}$ of 6.0 is within the range considered favorable for vegetable crop production. The chemical characteristics of the nutrient sources used for second experiment (Table 2) reveals that human urine as a nitrogen source had a concentration of $0.57 \% \mathrm{~N}$ while the phosphorus concentration was $0.01 \%$ and Ogun rock phosphate (ORP) contained $0.43 \% \mathrm{P}$.

\subsection{Experiment 1}

\subsubsection{Tomato Shoot Biomass}

The effects of $\mathrm{N}$ and $\mathrm{P}$ fertilizer treatments and varieties were significant on 
Table 1. Pre-cropping physicochemical properties of the experimental soil used.

\begin{tabular}{|c|c|}
\hline Soil Properties & Value \\
\hline $\mathrm{pH}\left(1: 1, \mathrm{H}_{2} \mathrm{O}\right)$ & 6.0 \\
\hline Organic C (g/kg) & 13.8 \\
\hline Total N (g/kg) & 1.0 \\
\hline Available P (mg/kg) & 3 \\
\hline \multicolumn{2}{|c|}{ Exchangeable Bases (cmol/kg) } \\
\hline $\mathrm{Ca}$ & 6.1 \\
\hline $\mathrm{Mg}$ & 0.3 \\
\hline $\mathrm{K}$ & 0.5 \\
\hline Exchangeable Acidity & 0.6 \\
\hline \multicolumn{2}{|c|}{ Extractable Micronutrient (mg/kg) } \\
\hline Mn & 312 \\
\hline $\mathrm{Cu}$ & 24.7 \\
\hline $\mathrm{Fe}$ & 286 \\
\hline \multicolumn{2}{|c|}{ Particle size distribution $(\mathrm{g} / \mathrm{kg})$} \\
\hline Clay & 78 \\
\hline Silt & 40 \\
\hline Sand & 882 \\
\hline Textural class (USDA) & Loamy sand \\
\hline
\end{tabular}

Table 2. Chemical analysis of the nutrient sources used for experiment 2.

\begin{tabular}{ccc}
\hline Nutrient Sources & \% Nitrogen & \% Phosphorus \\
\hline Human Urine & 0.57 & 0.01 \\
Ogun Rock Phosphate & 0.01 & 0.43 \\
\hline
\end{tabular}

fresh and dry shoot of tomato (Table 3). Application of 60 and $40 \mathrm{kgN}$ plus 20 $\mathrm{kgP} / \mathrm{ha}$ gave the highest fresh $(24.4 \mathrm{~g} / \mathrm{plant})$ and dry $(3.2 \mathrm{~g} / \mathrm{plant})$ shoot weight per plant, respectively while the control gave the least fresh $(3.01 \mathrm{~g} / \mathrm{plant})$ and dry (0.62 g/plant) shoot weights. Application of $\mathrm{P}$ at each level of $\mathrm{N}$ resulted in higher fresh shoot weight compared with the corresponding no P. With or without $\mathrm{P}$, fresh shoot weight of tomato increased with $\mathrm{N}$ rate from 0 to $40 \mathrm{~kg} / \mathrm{ha}$ while the trend was only observed without $\mathrm{P}$ for dry shoot weight. Fresh and dry shoot weights of tomato followed the order Roma savana $>$ Rio grande $>$ Roma $\mathrm{VF}>\mathrm{UC} 82 \mathrm{~B}$.

\subsubsection{Nutrient Content and Uptake by Tomato Plants}

Application of $80 \mathrm{kgN}+20 \mathrm{kgP} / \mathrm{ha}$ and $60 \mathrm{kgP} / \mathrm{ha}$ gave the highest values $(0.28 \%$ and $0.21 \%)$ for $\mathrm{N}$ and $\mathrm{P}$ contents respectively while the control gave the least values (Table 3). The control gave the least $(0.08 \mathrm{~g} / \mathrm{kg})$ value while fertilizer treatment 
Table 3. Effects of nitrogen and phosphorus fertilizer treatments and variety on shoot biomass, nutrient content and uptake by tomato plants in the first experiment.

\begin{tabular}{|c|c|c|c|c|c|c|c|}
\hline \multirow{2}{*}{\multicolumn{2}{|c|}{ Variables }} & \multirow{2}{*}{$\begin{array}{l}\text { Fresh shoot } \\
\text { weight } \\
\text { (g/plant) }\end{array}$} & \multirow{2}{*}{$\begin{array}{l}\text { Dry shoot } \\
\text { weight } \\
\text { (g/plant) }\end{array}$} & \multicolumn{2}{|c|}{$\begin{array}{c}\text { Nutrient Content } \\
\text { (\%) }\end{array}$} & \multicolumn{2}{|c|}{$\begin{array}{l}\text { Nutrient Uptake } \\
(\mathrm{g} / \mathrm{kg})\end{array}$} \\
\hline & & & & $\mathrm{N}$ & $\mathrm{P}$ & $\mathrm{N}$ & $\mathrm{P}$ \\
\hline \multicolumn{8}{|c|}{$\underline{\text { Fertilizer Treatment }}(\mathrm{kg} / \mathrm{ha})$} \\
\hline $\mathrm{N}$ & $\mathrm{P}$ & & & & & & \\
\hline \multirow[t]{2}{*}{0} & 0 & $3.01^{\mathrm{h}}$ & $0.62^{\mathrm{g}}$ & $0.15^{\mathrm{f}}$ & $0.06^{\mathrm{d}}$ & $0.08^{\mathrm{f}}$ & $0.05^{\mathrm{g}}$ \\
\hline & 20 & $18.59^{\mathrm{d}}$ & $2.74^{\mathrm{b}}$ & $0.16^{\mathrm{f}}$ & $0.09^{c}$ & $0.43^{\mathrm{c}}$ & $0.25^{\mathrm{d}}$ \\
\hline \multirow[t]{2}{*}{20} & 0 & $8.74^{\mathrm{f}}$ & $1.14^{\mathrm{f}}$ & $0.19^{\mathrm{d}}$ & $0.06^{\mathrm{d}}$ & $0.21^{\mathrm{e}}$ & $0.06^{\mathrm{g}}$ \\
\hline & 20 & $19.68^{c}$ & $2.69^{c}$ & $0.22^{\mathrm{b}}$ & $0.06^{\mathrm{d}}$ & $0.62^{\mathrm{b}}$ & $0.14^{\mathrm{e}}$ \\
\hline \multirow[t]{2}{*}{40} & 0 & $19.66^{\mathrm{c}}$ & $2.57^{\mathrm{d}}$ & $0.17^{\mathrm{e}}$ & $0.08^{\mathrm{c}}$ & $0.42^{\mathrm{c}}$ & $0.24^{\mathrm{d}}$ \\
\hline & 20 & $21.15^{\mathrm{b}}$ & $3.21^{\mathrm{a}}$ & $0.19^{\mathrm{d}}$ & $0.16^{\mathrm{b}}$ & $0.63^{\mathrm{b}}$ & $0.50^{\mathrm{b}}$ \\
\hline \multirow[t]{2}{*}{60} & 0 & $7.49^{\mathrm{g}}$ & $1.07^{\mathrm{f}}$ & $0.21^{\mathrm{c}}$ & $0.07^{\mathrm{c}}$ & $0.21^{\mathrm{e}}$ & $0.08^{\mathrm{f}}$ \\
\hline & 20 & $24.39^{\mathrm{a}}$ & $2.68^{\mathrm{c}}$ & $0.21^{\mathrm{c}}$ & $0.20^{\mathrm{a}}$ & $0.59^{c}$ & $0.62^{\mathrm{a}}$ \\
\hline \multirow[t]{2}{*}{80} & 0 & $11.49^{\mathrm{e}}$ & $1.40^{\mathrm{e}}$ & $0.21^{\mathrm{c}}$ & $0.07^{\mathrm{f}}$ & $0.34^{\mathrm{d}}$ & $0.09^{\mathrm{f}}$ \\
\hline & 20 & $18.45^{\mathrm{d}}$ & $2.62^{\mathrm{d}}$ & $0.28^{\mathrm{a}}$ & $0.15^{\mathrm{b}}$ & $0.65^{\mathrm{a}}$ & $0.38^{c}$ \\
\hline \multicolumn{8}{|c|}{ Tomato Variety } \\
\hline \multicolumn{2}{|c|}{ Rio Grande } & $16.94^{\mathrm{b}}$ & $2.39^{\mathrm{b}}$ & $0.18^{c}$ & $0.12^{\mathrm{a}}$ & $0.44^{c}$ & $0.34^{\mathrm{b}}$ \\
\hline \multicolumn{2}{|c|}{ Roma Savana } & $19.96^{\mathrm{a}}$ & $2.63^{\mathrm{a}}$ & $0.20^{\mathrm{b}}$ & $0.12^{\mathrm{a}}$ & $0.53^{\mathrm{a}}$ & $0.35^{\mathrm{a}}$ \\
\hline \multicolumn{2}{|c|}{ Roma VF } & $15.22^{\mathrm{c}}$ & $1.95^{\mathrm{c}}$ & $0.24^{\mathrm{a}}$ & $0.07^{\mathrm{c}}$ & $0.45^{\mathrm{b}}$ & $0.15^{\mathrm{c}}$ \\
\hline \multicolumn{2}{|c|}{ UC82B } & $8.94^{\mathrm{d}}$ & $1.32^{\mathrm{d}}$ & $0.17^{\mathrm{d}}$ & $0.09^{\mathrm{b}}$ & $0.25^{\mathrm{c}}$ & $0.12^{\mathrm{d}}$ \\
\hline \multicolumn{8}{|c|}{ Standard Error of Difference } \\
\hline \multicolumn{2}{|c|}{ Fertilizer } & $0.058^{\star * *}$ & $0.024^{\star * *}$ & $0.0005^{\star * *}$ & $0.005^{* * *}$ & $0.005^{\star * *}$ & $0.004^{* * *}$ \\
\hline \multicolumn{2}{|c|}{ Variety } & $0.037^{* * *}$ & $0.015^{\star * *}$ & $0.0004^{* * *}$ & $0.0004^{* * *}$ & $0.003^{* * *}$ & $0.003^{* * *}$ \\
\hline \multicolumn{2}{|c|}{$\mathrm{N} \& \mathrm{P} \times$ Variety } & $0.116^{\star * *}$ & $0.048^{\star * *}$ & $0.001^{* * *}$ & $0.0011^{\star * *}$ & $0.011^{\star * *}$ & $0.008^{* * *}$ \\
\hline
\end{tabular}

N: Nitrogen; P: Phosphorus; ${ }^{* *}$ : significant at $<0.001$; ns: not significant at $5 \%$; means with the same letter(s) in the same column are not significantly different (DMRT, $>5 \%$ ).

of $80 \mathrm{kgN}+20 \mathrm{kgP} / \mathrm{ha}$ gave the highest $(0.65 \mathrm{~g} / \mathrm{kg})$ value of nitrogen uptake. Application of $60 \mathrm{kgN}+20 \mathrm{kgP} / \mathrm{ha}$ had the highest $(0.62 \mathrm{~g} / \mathrm{kg})$ value and the control gave the least $(0.05 \mathrm{~g} / \mathrm{kg})$ value for phosphorus uptake by tomato. Roma savana had the highest $\mathrm{P}$ content and $\mathrm{N}$ and $\mathrm{P}$ uptake while Roma VF had the highest $\mathrm{N}$ content. The least $\mathrm{N}$ content and $\mathrm{N}$ and $\mathrm{P}$ uptake were observed with UC82B while Roma VF had the least P content.

\subsubsection{Nutrient Use Efficiency by Tomato Plant}

The nutrient (nitrogen and phosphorus) use efficiency by tomato varieties (Table 4) with $\mathrm{N}$ application levels either with $\mathrm{P}$ or without $\mathrm{P}$ application were significant. On dry shoot weight (biomass) basis, nitogen use efficiency of plants treated with sole application of nitrogen (without $\mathrm{P}_{0}$ ) was at maximum $(9.7 \mathrm{~g} / \mathrm{g}$ ) 
Table 4. Effects of fertilizer treatments on nutrient use efficiency of tomato plant in experiment 1 .

\begin{tabular}{|c|c|c|c|}
\hline \multirow{2}{*}{ Variables } & \multicolumn{2}{|c|}{ N U E (g/g) } & P U E (g/g) \\
\hline & $\mathrm{P}_{0}$ & $\mathrm{P}_{20}$ & $\mathrm{P}_{20}$ \\
\hline
\end{tabular}

Dry shoot weight basis

N Level (kgN/ha)

$\begin{array}{llcl}0 & 0^{\mathrm{d}} & 0^{\mathrm{d}} & 8.5^{\mathrm{a}} \\ 20 & 6.8^{\mathrm{b}} & 19.5^{\mathrm{a}} & 6.2^{\mathrm{c}} \\ 40 & 9.7^{\mathrm{a}} & 13.1^{\mathrm{b}} & 3.6^{\mathrm{e}} \\ 60 & 1.5^{\mathrm{d}} & 6.9^{\mathrm{c}} & 6.4^{\mathrm{b}} \\ 80 & 2.0^{\mathrm{c}} & 5.1^{\mathrm{d}} & 4.8^{\mathrm{d}}\end{array}$

$\underline{\text { Tomato Variety }}$

$\begin{array}{cccc}\text { Rio grande } & 3.6^{\mathrm{c}} & 7.0^{\mathrm{d}} & 8.3^{\mathrm{a}} \\ \text { Roma savana } & 4.0^{\mathrm{b}} & 10.0^{\mathrm{b}} & 5.3^{\mathrm{b}} \\ \text { Roma VF } & 6.7^{\mathrm{a}} & 10.6^{\mathrm{a}} & 4.8^{\mathrm{c}} \\ \text { UC82B } & 1.7^{\mathrm{d}} & 8.9^{\mathrm{c}} & 5.3^{\mathrm{b}} \\ & & \text { Fresh fruit weight basis }\end{array}$

$\mathrm{N}$ Level (kgN/ha)

$\begin{array}{cccc}0 & 0 & 0^{\mathrm{b}} & 29.7 \\ 20 & 8.3 & 103.2^{\mathrm{a}} & 49.3 \\ 40 & 25.6 & 63.0^{\mathrm{a}} & 48.2 \\ 60 & 36.3 & 85.2^{\mathrm{a}} & 50.0 \\ 80 & 30.7 & 42.5^{\mathrm{ab}} & 53.0\end{array}$

Tomato Variety

$\begin{array}{cccc}\text { Rio grande } & 25.5 & 106.3^{\mathrm{a}} & 53.4 \\ \text { Roma savana } & 32.5 & 66.2^{\mathrm{a}} & 34.5 \\ \text { Roma VF } & 10.9 & 9.9^{\mathrm{b}} & 43.6 \\ \text { UC82B } & 11.9 & 52.8^{\mathrm{ab}} & 52.7\end{array}$

Nue: nitrogen use efficiency; Pue: phosphorus use efficiency; p0: without application of p; p20: with application of $20 \mathrm{kgP} / \mathrm{ha}$; means with the same letter(s) in the same column are not significantly different (DMRT, $>5 \%$ ).

at application level of $40 \mathrm{kgN} / \mathrm{ha}$, followed by plants treated with $20 \mathrm{kgN}(6.8$ $\mathrm{g} / \mathrm{g}), 80 \mathrm{kgN}(2.0 \mathrm{~g} / \mathrm{g})$, and $60 \mathrm{kgN}(1.5 \mathrm{~g} / \mathrm{g}) . \mathrm{N}$ use efficiency of plants treated with combined application of $\mathrm{N}$ and $\mathrm{P}$ fertilizer (with $\mathrm{P}_{20}$ ) decreased with increase in nitrogen levels ( 0 to $80 \mathrm{kgN} / \mathrm{ha}$ ) in the order: $20 \mathrm{kgN}+20 \mathrm{kgP} / \mathrm{ha}>40$ $\mathrm{kgN}+20 \mathrm{kgP} / \mathrm{ha}>60 \mathrm{kgN}+20 \mathrm{kgP} / \mathrm{ha}>80 \mathrm{kgN}+20 \mathrm{kgP} / \mathrm{ha}$, with the respective $\mathrm{N}$ use efficiency values being 19.5, 13.1, 6.9 and $6.1 \mathrm{~g} / \mathrm{g}$. Phosphorus use efficiency (with $\mathrm{P}_{20}$ ) was at mximum at application of $0 \mathrm{kgN}+20 \mathrm{kgP} / \mathrm{ha}(8.5 \mathrm{~g} / \mathrm{g})$ followed by $60 \mathrm{kgN}+20 \mathrm{kgP} / \mathrm{ha}(6.4 \mathrm{~g} / \mathrm{g}), 20 \mathrm{kgN}+20 \mathrm{kgP} / \mathrm{ha}(6.2 \mathrm{~g} / \mathrm{g}), 80 \mathrm{kgN}$ 
$+20 \mathrm{kgP} / \mathrm{ha}(4.8 \mathrm{~g} / \mathrm{g})$ and $40 \mathrm{kgN}+20 \mathrm{kgP} / \mathrm{ha}(3.6 \mathrm{~g} / \mathrm{g})$, in that decreasing order. Roma VF had a maximum nitrogen use efficiency with $\left(\mathrm{P}_{20}\right)$ or without $\left(\mathrm{P}_{0}\right)$ application of $\mathrm{P}$ than Roma savana, Rio grande and UC82B. Phosphorus use efficiency was at maximum for Rio grande $(18.3 \mathrm{~g} / \mathrm{g})$ while UC82B and Roma savana similarly utilized phosphorus $(5.3 \mathrm{~g} / \mathrm{g}$ ) while Roma VF had the least $(4.8 \mathrm{~g} / \mathrm{g})$. On fresh fruit weight basis, $\mathrm{N}$ use efficiency increased as plants were increasingly supplied with with sole application of nitrogen $\left(\mathrm{N}+\mathrm{P}_{0}\right)$ but there was a decline in the efficiency of plant to use $\mathrm{N}$ above application of $60 \mathrm{kgN} / \mathrm{ha}(36.3 \mathrm{~g} / \mathrm{g})$. Though, $\mathrm{N}$ use efficiency at application of $80 \mathrm{kgN} / \mathrm{ha}(30.7 \mathrm{~g} / \mathrm{g})$ was higher than plants treated with $40 \mathrm{~kg} \mathrm{~N} / \mathrm{ha}(25.6 \mathrm{~g} / \mathrm{g})$ and $20 \mathrm{kgN} / \mathrm{ha}(8.3 \mathrm{~g} / \mathrm{g})$.

$\mathrm{N}$ use efficiency of plants treated with combined application of $\mathrm{N}$ and $\mathrm{P}$ fertilizers was highest at application of $20 \mathrm{kgN}+20 \mathrm{kgP} / \mathrm{ha}(103.2 \mathrm{~kg} / \mathrm{kg})$ but other treatments were comparable to the corresponding maximum. P use efficiency of plants treated with combined application of $\mathrm{N}$ and $\mathrm{P}$ fertilizers had response to phosphorus fertilizer in the order: $80 \mathrm{kgN}+20 \mathrm{kgP} / \mathrm{ha}>60 \mathrm{kgN}+20 \mathrm{kgP} / \mathrm{ha}>$ $20 \mathrm{kgN}+20 \mathrm{kgP} / \mathrm{ha}>40 \mathrm{kgN}+20 \mathrm{kgP} / \mathrm{ha}>0 \mathrm{kgN}+20 \mathrm{kgP} / \mathrm{ha}$, the respective phosphorus use effieciency values being $53,50,49,48$ and $29 \mathrm{~g} / \mathrm{g}$. The tomato varities had response to sole application of $\mathrm{N}$ fertilizer $\left(\mathrm{N}+\mathrm{P}_{0}\right)$ and combined applicaton of $\mathrm{N}$ with $\mathrm{P}$ fertilizers in the order: Roma savanna $>$ Rio grande $>$ UC82B $>$ Roma VF as well as Rio grande $>$ Roma savanna $>$ UC82B $>$ Roma VF respectively. Varieties had response to phosphorus applied in application of $\mathrm{N}$ with P fertilizers in this order: Rio grande $>$ UC82B $>$ Roma VF $>$ Roma savana. On dry shoot weight and fresh fruit weight bases, plants treated with nitrogen (0 to $80 \mathrm{kgN} / \mathrm{ha}$ ) with $20 \mathrm{kgP} / \mathrm{ha}$ had higher $\mathrm{N}$ use efficiency than sole application of $\mathrm{N}$.

\subsection{Experiment 2}

\subsubsection{Tomato Shoot Biomass}

The fresh tomato shoot weight (Table 5) were significantly $(\mathrm{P}<0.01)$ affected by fertilizer treatments. Application of urine + ORP had the maximum fresh shoot weight ( $32.5 \mathrm{~g} / \mathrm{plant})$ but the effects of urea + SSP $(27.1 \mathrm{~g} / \mathrm{plant})$ and urea + SSP + urine + ORP (25.9 g/plant) were comparable with each other as well as the control (untreated plant) had the least fresh shoot ( $21.5 \mathrm{~g} /$ plant) weight. Effects of fertilizer treatments and varieties on dry shoot weight $g$ per plant were significant $(\mathrm{P}<0.05)$ across the fertilizer treatments. Application of urine + ORP had the highest dry shoot weight $(5.46 \mathrm{~g} /$ plant) while the control had the least (3.38 g/plant). Roma savana gave a dry shoot weight ( $4.29 \mathrm{~g} / \mathrm{plant})$ higher than Rio grande $(4.27 \mathrm{~g} /$ plant $)$ which was comparable to the maximum.

\subsubsection{Nutrient Content and Uptake by Tomato Plant}

The $\mathrm{N}$ content of tomato leaves were significant for all the treatments applied. Application of urea + SSP gave a maximum N content (0.29\%), while urine + ORP $(0.26 \%)$ and urea + SSP + urine + ORP $(0.22 \%)$ had $\mathrm{N}$ content comparable to the maximum whereas the control resulted to the least $\mathrm{N}$ content $(0.19 \%)$. 
Table 5. Effects of fertilizer treatments and variety on shoot biomass, nutrient content and uptake by tomato plants in the second experiment.

\begin{tabular}{|c|c|c|c|c|c|c|}
\hline \multirow{2}{*}{ Variables } & \multirow{2}{*}{$\begin{array}{c}\text { Fresh shoot } \\
\text { weight } \\
\text { (g/plant) }\end{array}$} & \multirow{2}{*}{$\begin{array}{l}\text { Dry shoot } \\
\text { weight } \\
\text { (g/plant) }\end{array}$} & \multicolumn{2}{|c|}{$\begin{array}{l}\text { Nutrient content } \\
\text { (\%) }\end{array}$} & \multicolumn{2}{|c|}{$\begin{array}{l}\text { Nutrient uptake } \\
(\mathrm{g} / \mathrm{kg})\end{array}$} \\
\hline & & & $\mathrm{N}$ & $\mathrm{P}$ & $\mathrm{N}$ & $\mathrm{P}$ \\
\hline \multicolumn{7}{|l|}{ Fertilizer Types } \\
\hline Control & $21.5^{\mathrm{b}}$ & $3.38^{\mathrm{d}}$ & $0.19^{\mathrm{b}}$ & $0.19^{\mathrm{b}}$ & $0.60^{c}$ & $0.65^{\mathrm{c}}$ \\
\hline Urea + SSP & $27.1^{\mathrm{ab}}$ & $4.27^{\mathrm{ab}}$ & $0.29^{\mathrm{a}}$ & $0.35^{\mathrm{a}}$ & $1.19^{\mathrm{ab}}$ & $1.52^{\mathrm{ab}}$ \\
\hline Urine + ORP & $32.5^{\mathrm{a}}$ & $5.46^{\mathrm{a}}$ & $0.26^{\mathrm{ab}}$ & $0.35^{\mathrm{a}}$ & $1.34^{\mathrm{a}}$ & $1.97^{\mathrm{a}}$ \\
\hline Urea + SSP + urine + ORP & $25.9^{\mathrm{ab}}$ & $4.01^{\mathrm{c}}$ & $0.22^{\mathrm{ab}}$ & $0.26^{\mathrm{ab}}$ & $0.89^{\mathrm{bc}}$ & $1.05^{\mathrm{bc}}$ \\
\hline \multicolumn{7}{|l|}{$\underline{\text { Variety }}$} \\
\hline Rio grande & 27.3 & 4.27 & 0.25 & 0.26 & 1.08 & 1.12 \\
\hline Roma Savana & 26.2 & 4.29 & 0.22 & 0.32 & 0.92 & 1.47 \\
\hline \multicolumn{7}{|l|}{ Standard error of difference } \\
\hline Fertilizer $\times$ Variety & $3.50^{\mathrm{ns}}$ & $0.77^{*}$ & $0.04^{\mathrm{ns}}$ & $0.07^{\mathrm{ns}}$ & $0.22^{\mathrm{ns}}$ & $0.38^{\mathrm{ns}}$ \\
\hline
\end{tabular}

${ }_{* * *}$ : significant at $<0.001$; ${ }^{*}$ s significant at $0.05 \mathrm{~ns}$ : not significant; means with the same letter(s) in the same column are not significantly different (DMRT, $>5 \%$ ).

The percentage $\mathrm{P}$ content ranges from $0.19 \%$ at control to $0.35 \%$, equally obtained by application of urine + ORP and urea + SSP. Plants treated with urine + ORP had the maximum value of $\mathrm{N}(1.34 \mathrm{~g} / \mathrm{kg})$ and $\mathrm{P}(1.97 \mathrm{~g} / \mathrm{kg})$ uptake. Urea + ORP and urea + SSP + urine + ORP had values comparable to each other while the control gave the least values for $\mathrm{N}(0.60 \mathrm{~g} / \mathrm{kg})$ and $\mathrm{P}(0.65 \mathrm{~g} / \mathrm{kg})$ uptake by tomato. Rio grande gave the highest values for $\mathrm{N}$ content and uptake while Roma savana gave the highest values for $\mathrm{P}$ content and uptake. Fertilizer treatments and variety interaction were not significant across the parameters observed except for dry shoot weight.

\subsubsection{Nutrient Use Efficiency by Tomato Plant}

On total dry shoot weight basis (Table 6), plants treated with organic fertilizer (urine + ORP) were more efficient in the use of nitrogen $(10.7 \mathrm{~kg} / \mathrm{kg}$ ) and phosphorus $(32.2 \mathrm{~kg} / \mathrm{kg}$ ) than inorganic fertilizer (urea + SSP) and OMF mixtures (urea + SSP + urine + ORP). On fresh fruit weight basis, plants treated with OMF mixtures (urea + SSP + urine + ORP) were more efficient in the use of nitrogen $(20.1 \mathrm{~kg} / \mathrm{kg})$ and phosphorus $(73.7 \mathrm{~kg} / \mathrm{kg}$ ) than organic fertilizer (urine + ORP) $(\mathrm{N}-10.1 \mathrm{~kg} / \mathrm{kg}, \mathrm{P}-30.2 \mathrm{~kg} / \mathrm{kg}$ ) and inorganic fertilizer (urea + SSP) (N-6.5 $\mathrm{kg} / \mathrm{kg}, \mathrm{P}-21.1 \mathrm{~kg} / \mathrm{kg}$ ). Furthermore, nitrogen and phosphorus use efficiencies were higher with Roma savana $(\mathrm{N}-11.2 \mathrm{~kg} / \mathrm{kg}, \mathrm{P}-40.2 \mathrm{~kg} / \mathrm{kg})$ than Rio grande $(\mathrm{N}-7.2 \mathrm{~kg} / \mathrm{kg}, \mathrm{P}-22.3 \mathrm{~kg} / \mathrm{kg})$.

\subsubsection{Quality Parameters of Tomato Varieties}

Tomato fruit proximate compositions were significantly influenced by fertilizer 
Table 6. Effects of fertilizer treatments on nutrient use efficiency by tomato plant in experiment 2.

\begin{tabular}{|c|c|c|}
\hline Variables & N U E (kg/kg) & P U E $(\mathrm{kg} / \mathrm{kg})$ \\
\hline & \multicolumn{2}{|c|}{ Dry shoot weight basis } \\
\hline \multicolumn{3}{|l|}{$\underline{\text { Fertilizer Types }}$} \\
\hline Control & 0 & 0 \\
\hline Urea + SSP & 4.4 & 13.2 \\
\hline Urine + ORP & 10.7 & 32.2 \\
\hline Urea + SSP + urine + ORP & 4.0 & 12.0 \\
\hline \multicolumn{3}{|l|}{$\underline{\text { Tomato Variety }}$} \\
\hline Rio grande & 1.8 & 5.5 \\
\hline \multirow[t]{2}{*}{ Roma savana } & 7.7 & 23.2 \\
\hline & \multicolumn{2}{|c|}{ Fresh fruit weight basis } \\
\hline \multicolumn{3}{|l|}{ Fertilizer Types } \\
\hline Control & 0 & 0 \\
\hline Urea + SSP & 6.5 & 21.1 \\
\hline Urine + ORP & 10.1 & 30.2 \\
\hline Urea + SSP + urine + ORP & 20.1 & 73.7 \\
\hline \multicolumn{3}{|l|}{ Tomato Variety } \\
\hline Rio grande & 7.2 & 22.3 \\
\hline Roma savana & 11.2 & 40.2 \\
\hline
\end{tabular}

Nue: nitrogen use efficiency; Pue: phosphorus use efficiency.

treatments (Table 7). The $\mathrm{pH}$ of the tomato fruit ranges from 5.1 in Rio grande $\times$ urine + ORP to 5.5 in Roma savana $\times$ urea + SSP and urine + ORP as well as Rio grande $\times$ urea + SSP + urine + ORP. Furthermore, application of urine + ORP caused a low $\mathrm{pH}$ of 5.3 comparable with the control (5.4), urea + SSP and urea + SSP + urine + ORP with the same $\mathrm{pH}$ (5.5) value. Fertilizer treatments had significant effects on fruit lycopene content of the two varieties used. The interaction effects of the two factors (fertilizer and variety) tested showed that Roma savana had the highest lycopene content $(4.0 \mathrm{mg} / 100 \mathrm{~g})$ which was obtained from control and urea + SSP. Application of urine + ORP gave the least (3.1 mg/100g) lycopene content obtained from Roma savana and Rio grande. Fertilizer treatment of urea + SSP and urea + SSP + urine + ORP had the highest lycopene content in Rio grande $(3.6 \mathrm{mg} / 100 \mathrm{~g})$.

Furthermore, application of urea + SSP had significant effect on the lycopene content with average mean of $(3.8 \mathrm{mg} / 100 \mathrm{~g})$ compared with control and urea + SSP + urine + ORP with the same value $(3.6 \mathrm{mg} / 100 \mathrm{~g})$. Plants treated with urine + ORP gave the least $(3.1 \mathrm{mg} / 100 \mathrm{~g})$ fruit lycopene content. Fertilizer treatments had significant effects on fruit ascorbic/vitamin $\mathrm{C}$ content of the two varieties used for the study. The interaction of the two factors (fertilizer and variety) 
Table 7. Effects of fertilizer treatments on some fruit proximate qualities of two varieties of tomato.

\begin{tabular}{|c|c|c|c|}
\hline \multirow{2}{*}{ Fertilizer Type } & \multicolumn{2}{|c|}{ Tomato Variety } & \multirow{2}{*}{ Mean } \\
\hline & Roma savana & Rio grande & \\
\hline \multicolumn{4}{|l|}{$\mathrm{pH}$} \\
\hline Control & 5.4 & 5.4 & $5.4^{\mathrm{b}}$ \\
\hline Urea + SSP & 5.5 & 5.5 & $5.5^{\mathrm{a}}$ \\
\hline Urine + ORP & 5.5 & 5.1 & $5.3^{c}$ \\
\hline Urea + SSP + urine + ORP & 5.5 & 5.5 & $5.5^{\mathrm{a}}$ \\
\hline Mean & 5.5 & 5.4 & \\
\hline \multicolumn{4}{|l|}{$\underline{\text { Lycopene }}(\mathrm{mg} / 100 \mathrm{~g})$} \\
\hline Control & $4.0^{\mathrm{a}}$ & $3.2^{\mathrm{b}}$ & $3.6^{\mathrm{b}}$ \\
\hline Urea + SSP & $4.0^{\mathrm{a}}$ & $3.6^{\mathrm{a}}$ & $3.8^{\mathrm{a}}$ \\
\hline Urine + ORP & $3.1^{\mathrm{c}}$ & $3.1^{\mathrm{b}}$ & $3.1^{\mathrm{c}}$ \\
\hline Urea + SSP + urine + ORP & $3.5^{\mathrm{b}}$ & $3.6^{\mathrm{a}}$ & $3.6^{\mathrm{b}}$ \\
\hline Mean & 3.7 & 3.4 & \\
\hline \multicolumn{4}{|l|}{ Ascorbic Acid (mg/100g) } \\
\hline Control & $75.5^{\mathrm{b}}$ & $65.7^{\mathrm{d}}$ & $70.6^{c}$ \\
\hline Urea + SSP & $63.0^{\mathrm{d}}$ & $78.6^{\mathrm{a}}$ & $70.8^{\mathrm{b}}$ \\
\hline Urine + ORP & $80.3^{\mathrm{a}}$ & $75.3^{\mathrm{b}}$ & $77.8^{\mathrm{a}}$ \\
\hline Urea + SSP + urine + ORP & $68.1^{\mathrm{c}}$ & $69.4^{\mathrm{c}}$ & $68.8^{\mathrm{d}}$ \\
\hline Mean & 71.7 & 72.3 & \\
\hline \multicolumn{4}{|l|}{$\beta$-Carotene $(\mu \mathrm{g} / 100 \mathrm{~g})$} \\
\hline Control & $841.7^{\mathrm{d}}$ & $986.7^{\mathrm{c}}$ & $914.2^{\mathrm{d}}$ \\
\hline Urea + SSP & $1118.3^{\mathrm{b}}$ & $1105.0^{\mathrm{a}}$ & $1111.7^{\mathrm{a}}$ \\
\hline Urine + ORP & $1182.7^{\mathrm{a}}$ & $995.0^{c}$ & $1088.8^{\mathrm{b}}$ \\
\hline Urea + SSP + urine + ORP & $1045.3^{\mathrm{c}}$ & $1061.7^{\mathrm{b}}$ & $1053.5^{\mathrm{c}}$ \\
\hline Mean & 1047.0 & 1037.1 & \\
\hline \multicolumn{4}{|l|}{$\underline{\text { Titratable Acidity }}(\mathrm{T} / 10)$} \\
\hline Control & $0.5^{\mathrm{b}}$ & $0.7^{\mathrm{a}}$ & $0.6^{\mathrm{b}}$ \\
\hline Urea + SSP & $0.5^{\mathrm{b}}$ & $0.6^{\mathrm{b}}$ & $0.6^{\mathrm{b}}$ \\
\hline Urine + ORP & $0.7^{\mathrm{a}}$ & $0.6^{\mathrm{b}}$ & $0.7^{\mathrm{a}}$ \\
\hline Urea + SSP + urine + ORP & $0.6^{\mathrm{ab}}$ & $0.6^{\mathrm{b}}$ & $0.6^{\mathrm{b}}$ \\
\hline Mean & 0.6 & 0.6 & \\
\hline
\end{tabular}

Means with the same letter(s) in the same column are not significantly different (DMRT, $>5 \%$ ).

tested showed that Roma savana had the highest fruit ascorbic acid/Vitamin C $(80.3 \mathrm{mg} / 100 \mathrm{~g})$ content with urine + ORP and the least $(63.0 \mathrm{mg} / 100 \mathrm{~g})$ with urea + ORP applied. Application of urea + ORP and untreated plant gave the highest $(78.6 \mathrm{mg} / 100 \mathrm{~g})$ and lowest $(65.7 \mathrm{mg} / 100 \mathrm{~g})$ respectively at Rio grande. Further- 
more, application of urine + ORP gave the highest average mean of $77.8 \mathrm{mg} / 100 \mathrm{~g}$ and urea + SSP + urine + ORP had the least $(68.8 \mathrm{mg} / 100 \mathrm{~g})$ ascorbic acid fruit content.

The interaction of the two factors tested on $\beta$-carotene/vitamin A content was highest $(1182.7 \mu \mathrm{g} / 100 \mathrm{~g})$ and lowest $(841.7 \mu \mathrm{g} / 100 \mathrm{~g})$ for the control and plants treated with urine + ORP respectively for Roma savana. Application of urea + SSP gave the highest $(1105.0 \mu \mathrm{g} / 100 \mathrm{~g})$ concentration of $\beta$-carotene and urine + ORP had the least $(986.7 \mu \mathrm{g} / 100 \mathrm{~g})$ for Rio grande. Furthermore, applications of urea + SSP gave the highest average mean $(1111.7 \mu \mathrm{g} / 100 \mathrm{~g})$ followed by urine + ORP $(1088.8 \mu \mathrm{g} / 100 \mathrm{~g})$, urea + SSP + urine + ORP $(1053.5 \mu \mathrm{g} / 100 \mathrm{~g})$ and control $(914.2 \mu \mathrm{g} / 100 \mathrm{~g})$. The interaction of the two factors tested on titratable acidity (T/10) was highest (0.7) with plants treated with urine + ORP compared with urea + SSP + urine + ORP (0.6) and lowest (0.5) at the control for Roma savana. Rio grande had the highest (0.7) titratable acidity content for the control while other treatments were comparable to one another (0.6). Furthermore, application of urine + ORP gave the highest mean (0.7) of titratable acidity compared with other fertilizer treatments with the same value (0.6).

\section{Discussion}

The pre-cropping soil analysis of the study indicated a low level of N, P and $\mathrm{K}$ which were inadequate to support optimum growth of tomato. The low levels of $\mathrm{N}, \mathrm{P}$ and $\mathrm{K}$ observed are expected to cause a depression in the rate of photosynthesis as plants growth is markedly restricted especially under $\mathrm{P}$ deficiency, which retards growth, tillering and delay fruiting. This finding corroborates earlier findings of [24] who reported that most of Nigerian soil is deficient in N, P and $\mathrm{K}$ even organic matter. The increase in nutrient content, uptake (experiment 1) in plants treated with $\mathrm{N}$ and $\mathrm{P}$ fertilizers compared with sole application of nitrogen alone supports the findings of [25], that the relative growth rate of tomato increases sharply as soil $\mathrm{P}$ and $\mathrm{K}$ concentration increases. The levels of $\mathrm{P}$ and $B$ in the soil are critical to tomato production since its deficiency suppresses leaf nitrogen concentration due to increase in leaf cytokinin levels.

There was higher $\mathrm{N}$ and $\mathrm{P}$ use efficiency in combined application of $\mathrm{N}$ and $\mathrm{P}$ fertilizers than sole application of $\mathrm{N}$ and the more the quantities of fertilizer used, the less the efficiency of the crop to use $\mathrm{N}$ and $\mathrm{P}$. This was in line with the report of [26] on P use efficiency by pepper and okra. High fresh, dry shoot weight (biomass) and nutrient uptake of plants nourished with organic (urine + ORP) fertilizer could be due to the fact that the materials contained sufficient nutrients but the nutrients are slowly released to the plants which prevented nutrient loss by leaching, thus improving nutrient use efficiency. This might have contributed to higher $\mathrm{N}$ and $\mathrm{P}$ use efficiency of organic fertilizer (urine + ORP) and OMF mixtures (urea + SSP + urine + ORP) on dry shoot weight and fresh fruit weight respectively than inorganic fertilizer (urea + SSP). It could be observed that urine + ORP based fertilizer gave a better plant performance in terms 
of nutrient use efficiency and quality than urea + SSP, which supports the findings of [27] that human urine-compost combination 1:2 or 2:1 gave improved yield, shelf life and soil fertility than mineral fertilizers (NPK 15:15:15). He reported that human urine could be a good fertilizer for producing tomatoes and if combined with compost, effects are better.

Fertilizer treatment of urine + ORP caused a low pH (5.3) of tomato. Fruit $\mathrm{pH}$ is important in fresh consumption as low $\mathrm{pH}$ enhances its taste and flavor. [28] stated that quality of fruit is related to its acidity. This finding also corroborates the findings of [29] that organic fertilizer (manure) irrespective of the type caused a lower $\mathrm{pH}$ of tomato fruit. The decrease in titratable acidity (TA) is as a result of the increase in $\mathrm{pH}$. The application of urine + ORP (which had a low $\mathrm{pH}$ than other treatments) had the highest TA. This relationship between $\mathrm{pH}$ and TA observed in this study agrees with the findings of [30].

In this study, the value of vitamin $\mathrm{C}$ content of the fruit ranges between 68.8 to $77.8 \mathrm{mg} / 100 \mathrm{~g}$ was higher than that of [3] with mean value ranging 15 to 23 $\mathrm{mg} / 100 \mathrm{~g}$; this difference observed might be due to varietal forms and fertilizer treatments. Lycopene content was highest in inorganic fertilizer (urea + SSP) followed by organic fertilizer (urine + ORP) and OMF mixtures (urea + SSP + urine + ORP). This observed trend corroborates the study of [31] and this might be connected with the molecular structure of lycopene as a liposoluble micronutrient thereby suggesting more tendencies to remain in semi-soluble form in inorganic fertilizer (urea + SSP) than in organic materials like urine + ORP, thus affecting the concentrations [32].

\section{Conflicts of Interest}

The authors declare no conflicts of interest regarding the publication of this paper.

\section{References}

[1] Ojo, M.A., Ibrahim, O.A. and Mohammed, U.S. (2009) Profitability and Production Efficiency of Small-Scale Irrigated Tomato Production in Niger State, Nigeria. Continental Journal of Agricultural Economics, 3, 16-22.

[2] FAOSTAT (2016) Food and Agriculture Organization Statistics (FAOSTAT). http://www.fao.org/faostat/en/\#data/QC

[3] Dumas, Y., Dadomo, M., Lucca, G.D. and Grolier, P. (2003) Effect of Environmental Factors and Agricultural Technologies on Antioxidant Content of Tomatoes. Journal of the Science of Food and Agriculture, 83, 369-383. https://doi.org/10.1002/jsfa.1370

[4] Babalola, D.A., Iroh, Y.O., Omonona, B.T. and Oyekanmi, M.O. (2010) Determinant of Postharvest Losses in Tomato Production: A Case Study of Imeko-Afon Local Government Area of Ogun State. Acta SATECH, 3, 14-18.

[5] Shiyam, J.O. and Binang, W.B. (2013) Effect of Poultry Manure and Plant Population on Productivity of Fluted Pumpkin (Telfaiaria occidentalis Hook F.) in Calabar, Nigeria. Journal of Organic Systems, 8, 29-35. 
[6] Oyedeji, S., Animasaun, D.A., Bello, A.A. and Agboola, O.O. (2014) Effect of NPK and Poultry Manure on Growth, Yield and Proximate Composition of Three Amaranths. Journal of Botany, 2014, Article ID: 828750, 6 p. https://doi.org/10.1155/2014/828750

[7] AdeOluwa, O.O., Adeoye, G.O. and Yusuff, S.A. (2009) Effects of Organic Nitrogen Fortifiers on Some Growth Parameters of Green Amaranths (Amaranthus caudatus L.). Renewable Agriculture and Food Systems, 24, 245-250. https://doi.org/10.1017/S1742170509990184

[8] Wolgast, M. (1993) Rena Vatten. Omtankarikretslopp. Uppsala. 18.

[9] Jönsson, H., RichertStintzing, A., Vinnerås, B. and Salomon, E. (2004) Guidelines on the Use of Urine and Faeces in Crop Production-Report 2004-2. Journal of American Society of Horticultural Science, 121, 164-168.

[10] Heinonen-Tanski, H., Sjöblom, A., Fabritius, H. and Karinen, P. (2007) Pure Human Urine Is a Good Fertilizer for Cucumbers. Bioresources Technology, 98, 214-217. https://doi.org/10.1016/j.biortech.2005.11.024

[11] Pradhan, S.K., Holopainen, J.K., Weisell, J. and Heinonen-Tanski, H. (2010) Human Urine and Wood Ash as Plant Nutrients for Red Beet (Beta vulgaris) Cultivation: Impacts on Yield Quality. Journal of Agriculture and Food Chemistry, 58, 2034-2039. https://doi.org/10.1021/jf9029157

[12] Villareal, M., Hernandez, S., Sanchez, P., Garcia, R.S., Osuma, T., Parra, S. and Armenta, A.D. (2006) Effecto de Cobrtura del Suelocon Leguminosas en Pendimiento y Calidad del Tomate. TERRA Latinoameriana, 24, 549-556.

[13] Chritou, M., Dumas, Y., Dimirkou, A. and Vassilion, Z. (1999) Nutrient Uptake by Processing Tomato in Greece. Acta Horticulture, 487, 219-223. https://doi.org/10.17660/ActaHortic.1999.487.30

[14] Cao, W.T. and Tibbbts, W. (1999) Response of Potatoes to Nitrogen Concentrations Differs with Nitrogen Forms. Journal of Plant Nutrition, 21, 615-623. https://doi.org/10.1080/01904169809365429

[15] Udo, E.J. and Ogunwale, J.A. (1986) Laboratory Manual for the Analysis of Soil, Plant and Water Samples. 2nd Edition, Imperial Binding Service, Ibadan, $174 \mathrm{p}$.

[16] Bouyoucos, G.J. (1962) Hydrometer Method Improved for Making Particle Size of Soils. Agronomy Journal, 54, 464-465. https://doi.org/10.2134/agronj1962.00021962005400050028x

[17] Walkely, A. and Black, I.A. (1934) An Examination of the Degtjareff Method for Determination of Organic Matter and Proposed Medication of the Chronic Acid Titration Method. Soil Science, 37, 29-38. https://doi.org/10.1097/00010694-193401000-00003

[18] Kamprath, E.J. (1967) Soil Acidity and Response to Liming. International Soil Testing Series. Technical Bulletin No. 4, North Carolina, 8 p.

[19] Jackson, M.L. (1958) Soil Chemical Analysis. Prentice Hall, Incorporation Englewood Cliffs, New York, 496p.

[20] Murphy, J. and Riley, J.P. (1962) A Modified Single Solution Method for the Determination of Phosphate in Natural Waters. Analytica Chimica Acta, 27, 31-36. https://doi.org/10.1016/S0003-2670(00)88444-5

[21] Okalebo, J.R., Gathua, K.W. and Woomer, P.L. (1993) Laboratory Methods of Soil and Plant Analysis. A Working Manual. Soil Chemistry Laboratory, the Kenya Agricultural Research Institute, National Agricultural Research Centre, MUGUGA, Kenya. The Tropical Soil Biology and Fertility Programme, Regional Office for 
Science and Technology for Africa, UNESCO, Nairobi, Kenya, 88p.

[22] Bremner, J.M. (1982) Total Nitrogen. In: Page, A.L., Miller, R.H. and Keeney, D.R., eds., Methods of Soil Analysis, American Society of Agronomy, Madison.

[23] Kitson, R.E. and Mellon, M.G. (1944) Colorimetric Determination of Phosphorus as Molybdivandophosphoric Acid. Industrial Engineering Chemistry and Analytical Edition, 16, 379-383. https://doi.org/10.1021/i560130a017

[24] Adeuayi, E.A., Chude, V.O., Adehusuji, L.O. and Olayiwola, S. (2002) Fertilizer Use and Management Practices for Crops in Nigeria. Federal Ministry of Agricultural and Rural Development, Abuja.

[25] De Groot, C.C., Marcelis, L.F.M., Van den Boogaard, R. and Lambers, H. (2002) Interactive Effects of Nitrogen and Irradiance on Growth and Partitioning of Dry Mass and Nitrogen in Young Tomato Plants. Functional Plant Biology, 29, 1319-1328. https://doi.org/10.1071/FP02087

[26] Akinrinde, E.A. and Adigun, I.O. (2005) Phosphorus Use Efficiency by Pepper (Capsicum frutescens) and Okra (Abelmoschus esculentum) at Different Phosphorus Fertilizer Application Levels on Two Tropical Soils. Journal of Applied Sciences, 5, 1785-1791. https://doi.org/10.3923/jas.2005.1785.1791

[27] AdeOluwa, O.O., Aworuwa, C.O. and Ogunsanya, O.E. (2016) Influence of Human Urine-Compost Mixture on Some Soil Fertility Properties, Yield and Shelf-life of Tomato (Solanum lycopersicon). American Journal of Experimental Agriculture, 11, 1-10. https://doi.org/10.9734/AJEA/2016/19823

[28] Kobel, F. (1956) Qualitatus bewertuny van pillanzlichen erzeugnissen hach geruch. IX: 1-7.

[29] Eivazi, A.R., Rastergarn, A.R., Habibzadeh, Y., Mogaddam A.F. and Khlilzadeh, G. (2013) Influence of Manure Fertilizers on Morpho-Physiological Traits of Tomato (Lycopersicon Escutentum Mill). Peak Journal of Agricultural Sciences, 1, 89-93.

[30] Anthon, G.E., LeStrange, M. and Barrett, D.M. (2011) Changes in pH, Acids, Sugars and Other Quality Parameters during Extended Vine Holding of Ripe Processing Tomatoes. The Journal of the Science of Food and Agriculture, 91, 1175-1181. https://doi.org/10.1002/jsfa.4312

[31] Afolayan, S.O., Ogedengbe, K., Lateef, S.A., Akintola, O.A. and Oladele, O.J. (2014) Response of Tomato (Lycopersicium lycopersicum, CV UC82B) to Drip Irrigation and Planting Conditions. African Journal of Agriculture Research, 9, 1543-1549. https://doi.org/10.5897/AJAR2012.476

[32] Djuric, Z. and Powell, L.C. (2001) Antioxidant Capacity of Lycopene-Containing Foods. International Journal of Food Science and Nutrition, 52, 143-149. https://doi.org/10.1080/713671775 